\section{Gall stone dissolution in man using an essential oil preparation}

Rowachol, a proprietary "essential oil" preparation, has been on the market for over 25 years and is freely available on prescription in the United Kingdom. There have been several reports of patients' gall stones disappearing after prolonged treatment with Rowachol. ${ }^{12} \mathrm{We}$ have previously shown that two capsules of it given three times a day for 48 hours $^{3}$ lowers the lithogenic index of human bile. Rowachol, like the bile acids chenodeoxycholic acid (CDCA) and ursodeoxycholic acid (UDCA), apparently reduces biliary cholesterol output relative to that of bile salts and phospholipids (and hence renders bile desaturated) by specifically inhibiting the activity of the enzyme controlling hepatic cholesterol synthesis, hydroxymethyl-glutamylcoenzyme A reductase (HMGCoAR). ${ }^{4}$ We decided to evaluate Rowachol as a possible cholelitholytic agent in a small number of patients with radiolucent gall stones. We report our preliminary findings.

\section{Patients, methods, and results}

Twenty-seven patients with gall stones either in the gall bladder or common bile duct, or both, were treated with Rowachol 1 capsule/10 kg body weight/ day. Three patients were withdrawn from the study. One of them continued to have frequent biliary colic, one defaulted from follow-up, and a third complained of soreness of her mouth three days after starting treatment. Clinical details of the remaining 24 patients are shown in the table. All patients had had an oral or intravenous cholangiogram within one month of starting treatment except cases 7 and 22 , who had a post-operative T-tube cholangiogram showing retained gall stones. The patient in case 24 had an intravenous cholangiogram that showed a dilated bile duct containing two medium-sized stones but no opacification of the gall bladder. The remaining 24 patients had radiolucent gall stones and "functioning" gall bladders. A blood sample was taken for liver function tests (serum bilirubin, alanine transaminase, $\gamma$-glutamyl transpeptidase, and alkaline phosphatase) and haemoglobin, ESR, white blood, and platelet count before and at six-weekly intervals after starting Rowachol. The effect of Rowachol on gall stone dissolution or disappearance was assessed by (1) follow-up by oral cholecystogram or intravenous cholangiogram after six months' treatment (three months in cases 1 and 22), and/or (2) cholecystectomy findings after three weeks' (case 24), six months' (case 9), or seven months' (cases 10 and 15) treatment respectively.
Rowachol was well tolerated and seemed free from side effects. No haematological abnormalities or biochemical evidence of hepatotoxicity were found in any of the 24 patients. Seven of the 24 patients showed radiological or surgical (or both) evidence of partial (cases $2,7,9$, and 19) or complete (cases 1, 22, and 24) dissolution or disappearance of their gall stones (table).

\section{Comment}

Gall stones do very occasionally dissolve or disappear without treatment, but Wolpers's ${ }^{5}$ findings indicate a spontaneous resolution rate of under $1 \%$ a year. Thus the $7 / 24$ response in about six months in our patients is unlikely to have occurred by chance. We conclude that Rowachol merits further investigation as a possible cholelitholytic agent either alone or perhaps in combination with CDCA or UDCA.

Rowa Limited, Bantry, Co Cork, Eire, manufacturers of Rowachol, will supply the chemical composition of their product on request.

We will send on request the detailed results of the liver function tests and blood examinations in our patients.

We thank Rowa Limited for supplying the Rowachol capsules. One of us (JD) was receiving a grant from Schering Chemicals Ltd. We also thank the physicians, surgeons, and general practitioners in the Nottingham area who referred patients to us.

${ }^{1}$ Sarreither, W, Medizinische Monatsschrift, 1955, 9, 97

${ }^{2}$ Hordinsky, B Z, Minnesota Medicine, 1971, 54, 649.

${ }^{3}$ Doran, J, Keighley, M R B, and Bell, G D, Gut, 1977, 18, A977.

4 Bell, G D, et al, British fournal of Clinical Pharmacology, 1978, 6, 454P.

5 Wolpers, C, in Bile Acids in Human Diseases, ed P Back and W Gerok, vol 2, p 171. New York, F K Schattauel Verlag Stuttgart, 1972.

(Accepted 1 November 1978)

University of Nottingham, Departments of Therapeutics and of Surgery, City Hospital, Nottingham NG5 1PB

G D BELL, MD, MRCP, senior lecturer in therapeutics J DORAN, BSC, FRCS, lecturer in surgery

Clinical details and outcome in 24 patients treated with Rowachol

\begin{tabular}{|c|c|c|c|c|c|c|c|c|}
\hline Case no & $\underset{(y)}{\text { Age }}$ & Sex & $\underset{(\mathrm{kg})}{\text { Weight }}$ & $\begin{array}{l}\text { Stone } \\
\text { size }\end{array}$ & $\begin{array}{c}\text { Gall } \\
\text { bladder }\end{array}$ & $\begin{array}{l}\text { Common } \\
\text { bile } \\
\text { duct }\end{array}$ & $\begin{array}{c}\text { Duration } \\
\text { of treatment } \\
\text { (months) }\end{array}$ & Outcome \\
\hline $\begin{array}{r}1 \\
2 \\
3 \\
4 \\
5 \\
6 \\
7 \\
8 \\
9 \\
10 \\
11 \\
12 \\
13 \\
14 \\
15 \\
16 \\
17 \\
18 \\
19 \\
20 \\
21 \\
22 \\
23 \\
24\end{array}$ & $\begin{array}{l}65 \\
41 \\
70 \\
65 \\
48 \\
41 \\
43 \\
77 \\
61 \\
51 \\
58 \\
22 \\
50 \\
48 \\
46 \\
71 \\
63 \\
36 \\
61 \\
43 \\
53 \\
32 \\
23 \\
80\end{array}$ & $\begin{array}{c}F \\
F \\
M \\
F \\
\text { M } \\
F \\
F \\
F \\
F \\
F \\
F \\
F \\
F \\
F \\
M \\
F \\
M \\
F \\
M \\
M \\
F \\
F \\
F \\
F \\
F\end{array}$ & $\begin{array}{l}81 \\
77 \\
76 \\
58 \cdot 5 \\
92 \cdot 5 \\
53 \cdot 5 \\
60 \\
58 \\
69 \cdot 9 \\
55 \cdot 8 \\
64 \\
76 \\
52 \cdot 6 \\
58 \cdot 5 \\
60 \cdot 3 \\
81 \cdot 6 \\
59 \cdot 9 \\
83 \cdot 5 \\
64 \cdot 4 \\
59 \cdot 4 \\
63 \\
70 \cdot 8 \\
60 \cdot 3 \\
70 \cdot 1\end{array}$ & $\begin{array}{c}\text { B + C } \\
\text { B+C } \\
\text { A } \\
\text { C } \\
\text { C } \\
\text { A } \\
\text { B+C } \\
\text { C } \\
\text { A } \\
\text { ABC } \\
\text { A } \\
\text { B } \\
\text { B+C } \\
\text { B+C } \\
\text { A } \\
\text { B } \\
\text { C } \\
\text { B+C } \\
\text { B+C } \\
\text { C } \\
\text { C } \\
\text { A } \\
\text { B } \\
\text { B }\end{array}$ & $\begin{array}{l}+ \\
+ \\
+ \\
+ \\
+ \\
+ \\
+ \\
+ \\
+ \\
+ \\
+ \\
+ \\
+ \\
+ \\
+ \\
+ \\
+ \\
+ \\
+ \\
+ \\
+ \\
\text { NF }\end{array}$ & $\begin{array}{l}+ \\
= \\
= \\
= \\
+ \\
= \\
= \\
= \\
= \\
= \\
= \\
= \\
= \\
= \\
= \\
+ \\
+\end{array}$ & $\begin{array}{r}6 \\
12 \\
6 \\
6 \\
6 \\
6 \\
12 \\
6 \\
7 \\
6 \\
6 \\
6 \\
6 \\
6 \\
6 \\
6 \\
6 \\
6 \\
6 \\
6 \\
6 \\
6 \\
6 \\
3 \text { weeks }\end{array}$ & 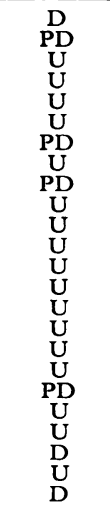 \\
\hline
\end{tabular}

Notes-Stone size: $A=$ gall stones $<5 \mathrm{~mm} ; \mathrm{B}=5-10 \mathrm{~mm} ; \mathrm{C}=>10 \mathrm{~mm} . \mathrm{NF}=$ non-functioning radiologically. Outcome of therapy: $\mathrm{U}=$ number and size of stones unchanged; $\mathrm{PD}=$ partial dissolution of stones; $\mathrm{D}=$ complete dissolution. 